\title{
An economic analysis of the Heterocarpus reedi and Cervimunida johni fisheries off northern-central Chile, from 1997 to 2000
}

\author{
Eduardo P. Pérez ${ }^{1,2}$ \\ ${ }^{1}$ Universidad Católica del Norte, Facultad de Ciencias del Mar \\ Departamento de Biología Marina, Casilla 117, Coquimbo, Chile \\ ${ }^{2}$ Centro de Estudios Avanzados en Zonas Áridas (CEAZA), La Serena, Chile
}

\begin{abstract}
The economic effects resulting from the diminishing catch per unit of effort (CPUE) in the nylon shrimp and squat lobster fishery off northern-central Chile from 1997 to 2000 were evaluated. A bio-technological simulation model was used that describes the physical and biological performance variables for the fishery. An economic submodel was incorporated to the original model in order to perform an integrated analysis of the crustacean fishery, including the catch and processing sub-sectors. The economic results, in conjunction with the data on catch and stock size, explained this fishery's dynamic off northern-central Chile during the study period. The total catch increased $21 \%$ between 1997 and 2000 and the final production increased $24 \%$, but the quasi rent of the variable costs increased only $11 \%$. The same period saw costs associated with fishing trips increase $117 \%$ and the total production cost increased $93 \%$. The study results showed that part of the profits were lost due to the decreased biomass of both resources and the excessive increase in the average production costs, which were explained by the increased fishing trip costs. In order to obtain a better representation of the fishery's performance, economic references points should be incorporated to complement the traditional biological (biomass) and fishery (CPUE, catches) proxies.
\end{abstract}

Key words: economics, nylon shrimp, squat lobster, quasi rent, Chile.

\section{Análisis económico de la pesquería de Hetercorpus reedi y Cervimunida johni en la zona centro norte de Chile, periodo 1997-2000}

\begin{abstract}
RESUMEN. Se analizó el efecto económico debido a la disminución de la captura por unidad de esfuerzo (CPUE) en la pesquería de camarón nailon y langostino amarillo en la zona norte y central de Chile durante el periodo 1997-2000. Se utilizó un modelo de simulación biológico-tecnológico que da cuenta de variables de desempeño físicas y biológicas. A este modelo se le incorporó un submodelo económico para realizar un análisis integrado de la pesquería de crustáceos que incluye el subsector de captura y procesamiento. Los resultados económicos obtenidos, sumados a los resultados de captura y de tamaño del stock permiten explicar la dinámica de esta pesquería en la zona centro-norte de Chile durante el período 1997-2000, donde la captura aumentó en 21\%, la producción final aumentó en 24\%, pero la cuasi renta de los costos variables aumentó sólo $11 \%$. En este mismo período los costos por marea incrementaron $117 \%$ y el costo total de producción aumentó 93\%. Los resultados mostraron que parte del beneficio económico se pierde debido a la disminución de la biomasa de ambos recursos y a un aumento excesivo en los costos medios de producción, que fueron explicados por el aumento en los costos de marea. Se recomienda incorporar puntos de referencia económicos en orden a tener una mejor representación del desempeño de la pesquería, como un complemento a los indicadores de desempeño biológicos (biomasa) y pesqueros (CPUE y captura) usados tradicionalmente.
\end{abstract}

Palabras clave: economía, camarón nailon, langostino amarillo, cuasi renta, Chile.

Corresponding author: Eduardo Pérez (eperez@ucn.cl) 


\section{INTRODUCTION}

Recently, Pérez (2005) described the dynamics of biomass, catches, and catch per unit of effort (CPUE, ton $\operatorname{trawl}^{-1}$ ) for the Heterocarpus reedi nylon shrimp fishery off northern Chile. The CPUE for both nylon shrimp and squat lobster progressively decreased from 1997 to 2000 (SUBPESCA, 2005a, 2005b; Quiroz et al., 2005). An earlier work by Pérez (2003) showed the same pattern for the squat lobster, Cervimunida johni, off northern Chile. Since these fisheries are managed through a system of a maximum catch limits (MCL) per vessel owner, with an annual global quota equal to the total permissible catch (TPC), a decrease in the CPUE is expected to imply an increase in the fishing effort (in number of trawls) as a way to reach the TPC established for the season. Pérez (2003) described a time limit for the daily number of trawls per vessel. Hence, the only way to maintain the TPC levels is by increasing the fishing period at sea, which could have economic consequences for the industry due to the possible increase in operation costs. In extreme cases (i.e. open access), the stock externalities caused by increased effort have been shown to result in a complete loss of the income generated by a resource (Seijo et al., 1997).
In this work, we analyze the bio-economic effect, mainly in terms of the increased catch costs, of the decreased CPUE on the nylon shrimp and squat lobster fishery off northern Chile between 1997 and 2000.

\section{MATERIALS AND METHODS}

This study was carried out off northern-central Chile (Fig. 1) between September 1997 and August 2000. The analysis was based on the bio-technological model developed for nylon shrimp (Heterocarpus reedi) and squat lobster (Cervimunida johni, Pleuroncodes monodon) (Pérez, 2003, 2005). This model was fed data and information provided by the fishing companies through the daily monitoring of the spatial and temporary dynamics of effort and the CPUE (ton trawl $^{-1}$ ) displayed by the fleet on nylon shrimp and squat lobster (Fig. 2, 3). An economic sub-model was incorporated into the original simulation model in order to perform an integrated analysis of the fisheries (Sparre \& Willmann, 1993) based on the information provided by the companies for the same time period.

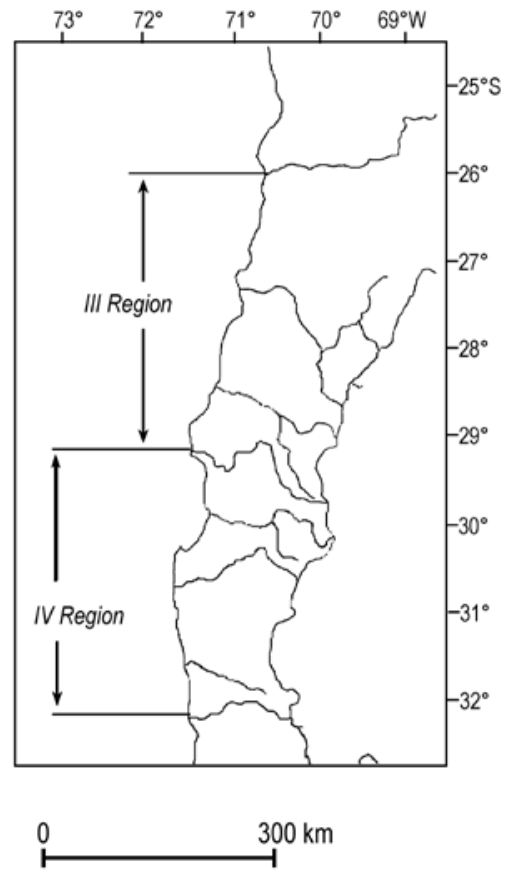

Figure 1. Geographic location for the study area, main landing ports at the central-northern Chile, and access regime for target species of the trawl fleet based in Coquimbo Bay. 

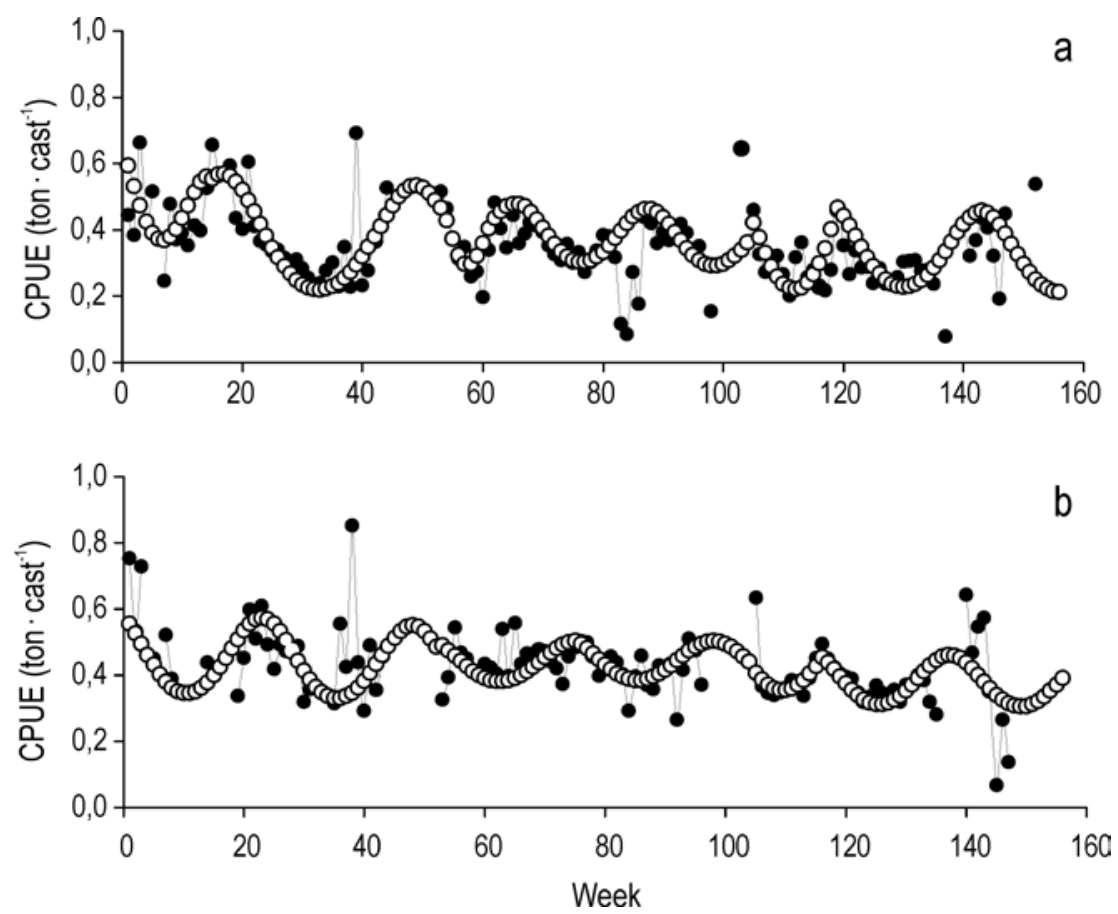

Figure 2. Dynamic for nylon shrimp CPUE (ton $\bullet^{-t r a w l}{ }^{-1}$ ) in the northern-central Chile. a) IV Region, and b) III Region. Calculated $(O)$ and observed $(\bullet)$ CPUE is shown, based on Pérez, 2003, 2005).
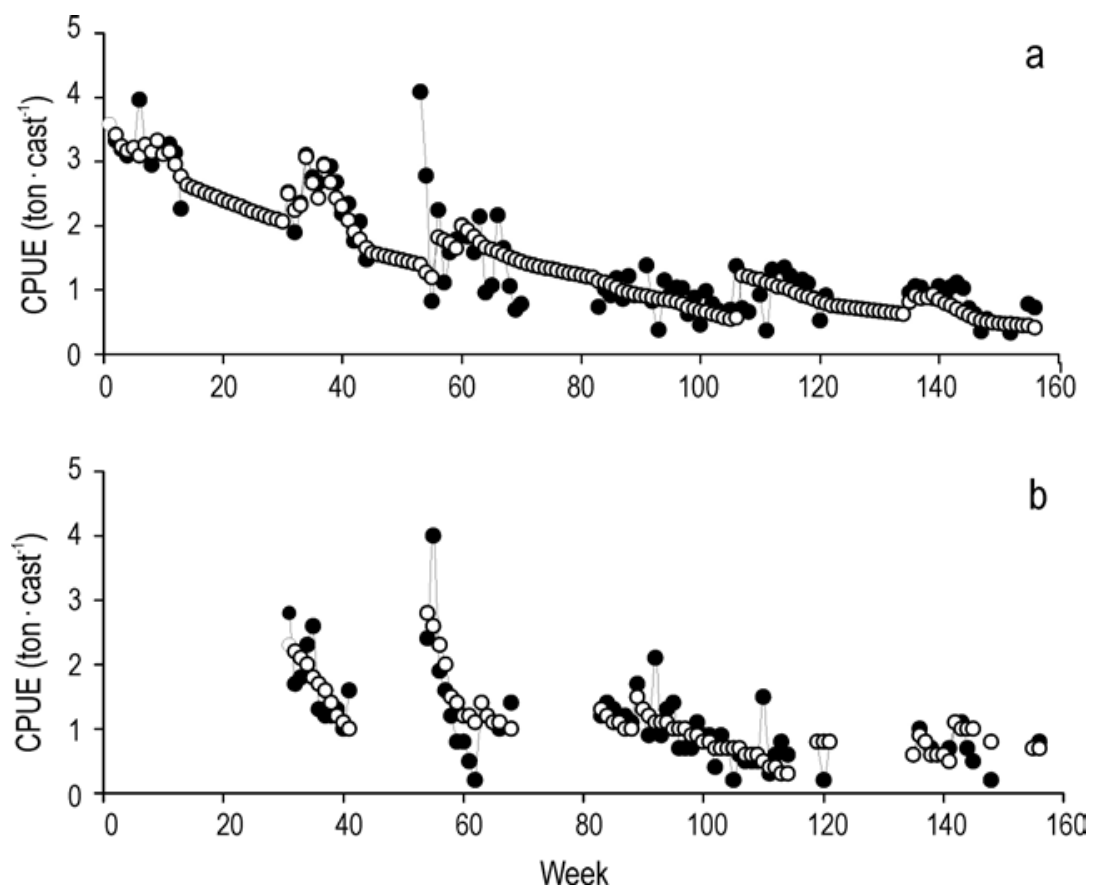

Figure 3. Dynamic for squat lobster CPUE (ton $\bullet^{-t_{a}} \mathrm{l}^{-1}$ ) in the northern-central Chile. a) III Region, and b) IV Region. Calculated $(O)$ and observed $(\bullet)$ CPUE is shown, based on Pérez, 2003). 
The results were described on the basis of annual seasons that stretched from September of one year to August of the next, according to the evaluation criterion of the Subsecretaría de Pesca, Chile. The three analyzed fishing seasons were called 97-98 (September 1997-August 1998), 98-99 (September 1998-August 1999), and 99-00 (September 1999August 2000).

Off northern-central Chile, the crustacean fishing industry is vertically integrated. In operational terms, the companies define the basic unit as a three-day long fishing trip. The costs of the fishing trip, processing, conversion factors, and market price of the final product (both nylon shrimp and squat lobster) are given in Table 1. In some cases, some companies have to buy raw materials from other companies in order to meet their stipulated export volumes. Although this practice is marginal, it is possible to define an ex-vessel market price for each resource (Table 1).

The fishing trip costs were determined by calculating the number of fishing trips per week $t$. By dividing the observed weekly catch by the average weekly CPUE (ton trawl ${ }^{-1}$ ), we get the total trawls per week. Thus, the number of fishing trips can be obtained by dividing the total number of trawls by the trawls per fishing trip. The total operational cost per week for fishing trips $\left(C M_{t}\right)$ can be determined as:

$$
C M_{t}=N M_{t} \cdot \operatorname{CoM}
$$

where $N M$ is the number of fishing trips and $C o M$ is the cost per fishing trip. Table 1 summarizes the items related to the costs per fishing trip.

There is an additional cost in the fleet, which is a bonus (paid to the vessel's captain and crew) that

Table 1. Economic information of the fleet and plant used to construct the simulation model for the nylon shrimp and squat lobster fisheries.

\begin{tabular}{lc}
\hline Variable costs per fishing trip & US\$ \\
\hline Fuel & 887 \\
Oil & 177 \\
Ice & 638 \\
Fishing gear replacement & 115 \\
Food & 177 \\
Engine maintenance & 89 \\
Vessel maintenance & 89 \\
Unloading & 443 \\
Docking & 44 \\
\hline Total cost per fishing trip & $\mathbf{2 , 6 6 0}$ \\
\hline Fishing trip days & 3 \\
Trawls per day (fleet average) & 3.8 \\
Trawls per fishing trip (fleet average) & 11.4 \\
Cost per trawl & 233 \\
Cost per box of nylon shrimp ex-vessel & 9.26 \\
Cost per box of squat lobster ex-vessel & 11.11 \\
& 5.56 \\
Cost per kilo of nylon shrimp & \\
Cost per kilo of squat lobster & $0.66-0.79$ \\
Conversion factor (fc ${ }_{\mathrm{i}}$ ) nylon shrimp raw material & 0.38 \\
Conversion factor (fc $\mathrm{i}_{\mathrm{i}}$ ) squat lobster raw material & 0.19 \\
Price of the nylon shrimp (US $\$ \cdot \mathrm{kg}^{-1}$ ) & 13 \\
Price of the squat lobster $\left(\mathrm{US} \$ \mathrm{~kg}^{-1}\right.$ ) & 11 \\
\hline
\end{tabular}


depends on the catch volume per species. Thus, the fleet's total cost per week is the sum of the total fishing trip cost plus the cost of the catch bonus per species $i\left(C B P_{t, i}\right)$. In the processing plant phase, there is an additional cost derived from the tailing process, which is calculated as a payment (Table 2) per kilo of the tailed species $\left(C D_{t, i}\right)$. The total variable cost per fishing season $\left(C V_{s}\right)$ is calculated as follows:

$$
C V_{S}=\sum_{t=1}^{n}\left(C M_{t}+\sum_{i=1}^{2}\left(C B P_{t, i}+C D_{t, i}\right)^{\prime}\right.
$$

Finally, the weekly total revenues $\left(\mathrm{IT}_{\mathrm{t}}\right.$ ) are calculated per species according to the following equation:

$$
I T_{t}=\sum_{\mathrm{l}=1}^{2} p_{i} \cdot Q_{t, i}
$$

where $p_{i}$ and $Q_{i}$ are the price per kilo and the kilos of final product of species $i$, respectively. These are calculated as:

$$
Q_{t, i}=C_{t, i} \cdot f c_{i}
$$

where $C_{t, i}$ is the catch of species $i$ in week $t$ and $f c_{i}$ is the conversion factor from raw material to final product for species $i$ (Table 1).

The quasi rent of the variable costs for each week $t$ is determined as:

$$
\text { quasi }_{t, i}=I T_{t, i}-C V_{t, i}
$$

(Seijo et al., 1997), so the quasi rent per fishing

\begin{tabular}{|c|c|c|c|c|}
\hline Salary & Position & US\$ & Number & Total \\
\hline \multirow[t]{4}{*}{ Vessel } & Captain & 236 & 1 & 236 \\
\hline & Motor technician & 122 & 1 & 122 \\
\hline & Crew member & 132 & 6 & 795 \\
\hline & & & Monthly total & 1,153 \\
\hline \multirow[t]{4}{*}{ Catch bonus (vessel) } & & $\begin{array}{l}\text { Nylon shrimp } \\
\left(\mathrm{US} \$ \cdot \mathrm{kg}^{-1}\right)\end{array}$ & $\begin{array}{c}\text { Squat lobster } \\
\left(\mathrm{US} \$ \cdot \mathrm{kg}^{-1}\right)\end{array}$ & \\
\hline & Captain & 0.0306 & 0.0149 & \\
\hline & Motor technician & 0.0153 & 0.0045 & \\
\hline & Crew member & 0.0090 & 0.0045 & \\
\hline Plant (tailing) & & 0.4730 & 0.4324 & \\
\hline
\end{tabular}
season is:

Table 2. Economic information on catch bonuses and tailing used to construct the simulation model for the nylon shrimp and squat lobster fisheries.

$$
\text { quasi }_{S, i}=\sum_{i=1}^{2} \sum_{t=1}^{n} \text { quasi }_{t, i}
$$

The total quasi rent for the fishery, then, is the sum of the quasi rent generated by both resources. The use of the quasi rent of the variable costs is justified by the lack of consideration of all the fixed costs in the accounting activities. Hence, the average production cost was calculated by dividing the total cost among the kilos of final product for each resource.

We must state explicitly that this integrated analysis is valid within the domain of distinctions that we can determine given certain limitations. a) Processing plants not only process raw material from catches, but are also able to process products other than those resulting from fishing. Thus, the domain of validity is restricted to profits derived from the exploitation and processing of crustaceans. b) Access to economic information on the companies is a delicate matter, as it is considered to be strategic information. Therefore, we only have available information about the cost per unit of effort and the value of the product elaborated from the raw material. Other fixed or variable costs of the land operations and administration were not available for this study, so the analysis only includes costs associated with the catch and the cost of tailing the product. c) Finally, all the economic values mentioned in the results are expressed in constant prices.

\section{RESULTS}

Between the first and the third season, the average production cost, i.e. the cost per kilo of final product, 
increased for both resources (Fig. 4a). In the case of nylon shrimp, it increased $131.3 \%$, from US $\$ 3.9$ to US $\$ 4.2 \mathrm{~kg}^{-1}(7.7 \%)$, whereas for squat lobster, it increased from US $\$ 1.6 \mathrm{~kg}^{-1}$ (97-98) to US $\$ 3.7$ $\mathrm{kg}^{-1}$ (99-00).

The quasi rent from the variable costs (Fig. 4b) fluctuated between US \$11 and US \$12.3 million dollars. Most of this was contributed by the nylon shrimp fishery, which increased annually. On the other hand, the quasi rent from squat lobster decreased from US $\$ 6$ (97-98) to US \$3 million dollars (99-00).

The nylon shrimp catch (Fig. 4c) increased
$110.5 \%$, from 2,653 tons in $97-98$ to 5,585 tons in 99-00. The squat lobster catch, however, decreased $20.7 \%$, from 5,468 to 4,337 tons.

The total number of fishing trips (Fig. 4d) increased for both species between the first and the third season. Fishing trips to catch squat lobster increased $106.5 \%$, from 232 in $97-98$ to 479 in $99-00$, whereas those for nylon shrimp catches increased $120 \%$, from 644 to 1,417 in the same fishing seasons. The increased number of fishing trips is reflected in the total variable costs of this item (Fig. 4e).

Despite the decrease in squat lobster plant pro-
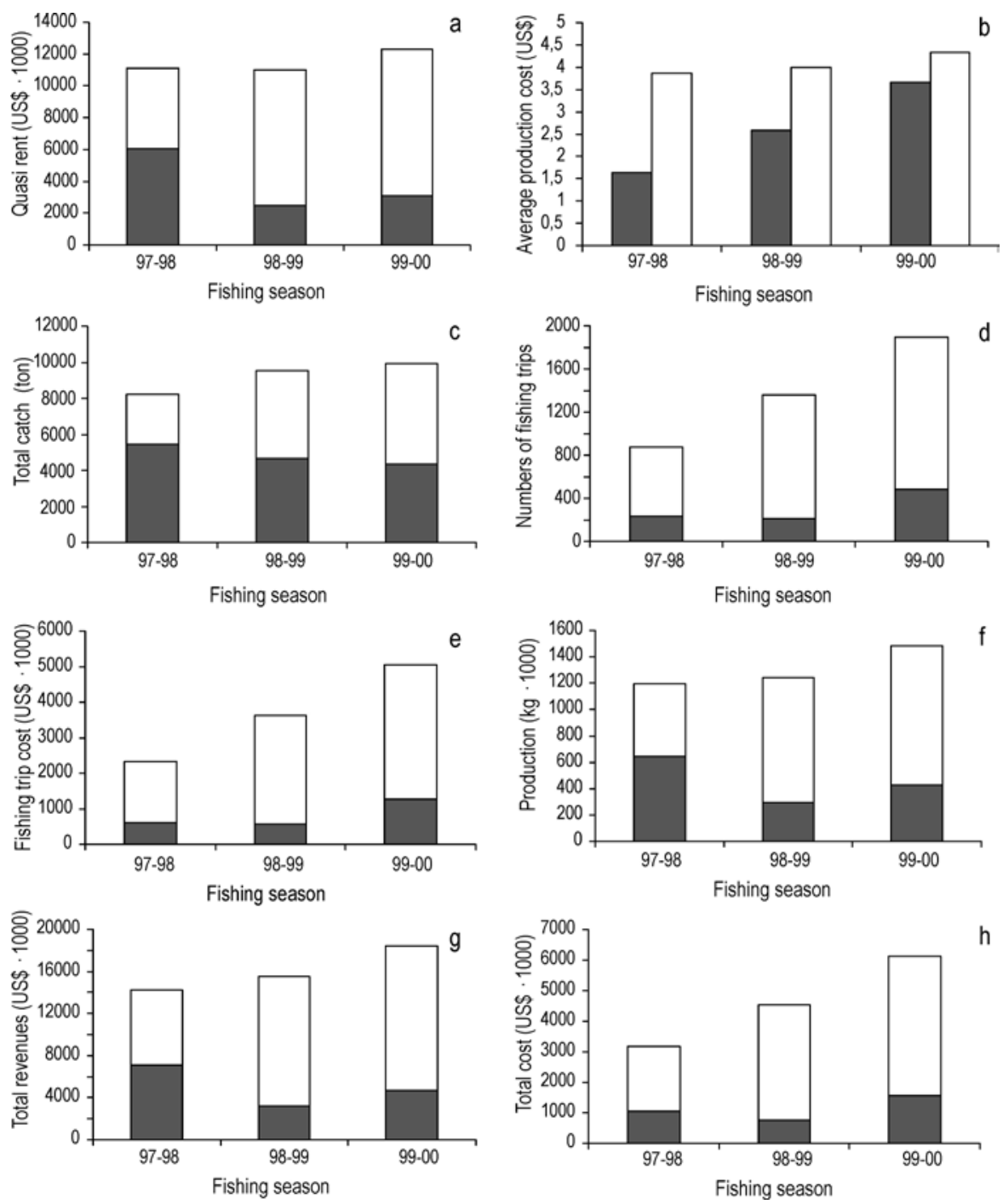

Figure 4. Results obtained for fishing period and resource. Squat lobster $(\square)$ and nylon shrimp ( $\square$ ). a) quasi rent of variable cost, b) average production cost, c) total catch, d) fishing trips, e) total cost by fishing trip, f) total production by processing, g) total revenues, and $h$ ) total variable costs. 
duction (Fig. 4f), the total revenues increased (Fig. 10) thanks to the increase in nylon shrimp production (Fig. 4f, 4g). Nevertheless, this increase in the total revenues were accompanied by an increment in the total variable costs (fleet and plant, Fig. 4h). Thus, whereas the final product increased $24 \%$ in quantity, from 1,196 tons in $97-98$ to 1,483 tons in 99-00, the total variable costs increased $92.8 \%$ (Fig. 4h). This increase in the variable costs maintained the quasi rent at the level of US \$11 million for the three seasons (Fig. 4a) despite the increased nylon shrimp catch and production.

\section{DISCUSSION}

The economic results, in conjunction with the data on catch and stock size (Pérez, 2003, 2005), allow us to explain the benthic crustacean fishery dynamics off northern-central Chile from 1997 to 2000 and the consequences observed later.

As of 1999, the crustacean fishery experienced a difficult period off northern-central Chile (SUBPESCA, 2005a, 2005b) because the TPC for the nylon shrimp fishery decreased throughout the area from 10,000 tons in 1997 to 8,300 tons in 1998 and then dropped drastically from 7,900 tons in 1999 to 4,000 tons in 2000 . In other words, in a four-year period, the TPC decreased $60 \%$. In the case of the squat lobster fishery in this same region, the TPC decreased from 6,000 tons in 1998 to 4,000 tons in 2000 , that is, by $33 \%$. This reduction in the TPC resulted in a substantial decline in the activities of fleets and plants. In 2002, some companies shut down and jobs were lost due to the social importance of this fishery in the catch and processing centers.

The behavior of the different performance variables for this period is consistent with the problems the fishery experienced in 2001 and 2002. The lower biomass of both resources (SUBPESCA, 2003, 2005a, 2005b; Pérez, 2003, 2005; Quiroz et $a l ., 2005)$ was consistent with the increase in average production costs due to the decline in the CPUE (Pérez, 2003, 2005), the need to increase the number of fishing trips, and costs associated with these trips. For example, the catch increased 21\% between 1997 and 2000 and the final production increased $24 \%$, whereas the quasi rent of variable costs increased only $11 \%$. In the same period, the fishing trip costs increased $117 \%$ and the total production cost increased $93 \%$. At the same time, the nylon shrimp biomass decreased 54\% (Pérez, 2005) and the squat lobster biomass decreased 67\% (Pérez, 2003). The decrease in biomass, followed by a lower CPUE (SUBPESCA, 2003, 2005a, 2005b; Pérez 2003, 2005; Quiroz et al., 2005), forced companies to make a greater effort in terms of the number of fishing trips, which caused an important increase in the production costs with the consequent loss of the expected profit. If the fixed costs related to the fleet, processing, and administration are considered, the economic benefits would decrease even more significantly. This result is consistent with the prediction of Seijo et al. (1997), in the sense that an extraction quota system, even if it can protect the resource biomass, results in the loss of the surplus benefit derived from the exploitation.

In this context, economic reference points are necessary to provide a better representation of the fishery performance (Seijo \& Caddy, 2000) complementary to the commonly used biological (biomass) and fishery (CPUE, catch) performance proxies (SUBPESCA, 2005a, 2005b). Moreover, the need arises to evaluate the bio-economic effects of administrative measures in the short term on the crustacean fishery in conjunction with the management practices within the companies. The results showed that part of the profits that could be generated by the resource are lost due to the combined effect of the biomass decrease in both resources and the excessive increase in the average production costs, which can be explained by the rise in the fishing effort costs in terms of the number of fishing trips.

\section{REFERENCES}

Pérez, E.P. 2003. Análisis bio-económico de la pesquería de crustáceos en la plataforma centro-norte de Chile. Tesis de Doctorado en Ciencias. Centro de Investigación y Estudios Avanzados IPN, Unidad Mérida, México, 117 pp.

Pérez, E.P. 2005. Un modelo simple para describir la dinámica de la biomasa del camarón nailon Heterocarpus reedi en Coquimbo, Chile. Invest. Mar., Valparaíso, 33(2): 131-142.

Quiroz, J.C., R. Wiff \& C. Montenegro. 2005. Factores que afectan las tasas de captura de langostino amarillo (Cervimunida johni) en la zona norte de Chile. Invest. Mar., Valparaíso, 33: 43-55.

Seijo, J.C., O. Defeo \& S. Salas. 1997. Bioeconomía pesquera: teoría, modelación y manejo. FAO, Doc. Téc. Pesca, 368: 176 pp.

Seijo, J.C. \& J.F. Caddy. 2000. Uncertainty in bioeconomic reference points and indicators of marine fisheries. Mar. Fresh. Res., 51: 477-483. 
Sparre, P.J. \& R. Willmann. 1993. BEAM 4. Analytical bio-economic simulation of space-structured multispecies and multifleet fisheries. FAO Comput. Inf. Ser., Fisheries, 1: 186 pp.

Subsecretaría de Pesca (SUBPESCA). 2003. Cuota global anual de captura de camarón nailon entre la II y la VIII Región, año 2004. Informe Técnico de Pesca (R. Pesq.), 102: 20 pp.

Received: 27 June 2006; Accepted: 6 August 2007
Subsecretaría de Pesca (SUBPESCA). 2005a. Cuota global anual langostino amarillo, (Cervimunida johni) III y IV Región, año 2006. Informe Técnico de Pesca (R. Pesq.), 134: 27 pp.

Subsecretaría de Pesca (SUBPESCA). 2005b. Cuota global anual de captura de camarón nailon (Heterocarpus reedi) entre la II y la VIII Región, año 2006. Informe Técnico de Pesca (R. Pesq.), 135: 25 pp. 